\title{
UJI STABILITAS FISIK FORMULASI SEDIAAN LIP BALM YANG MENGANDUNG EKSTRAK ETANOL BUAH LABU KUNING (Curcubita moschataD.)
}

\author{
Sheila Meitania Utami ${ }^{1}$, Humaira Fadhilah ${ }^{2}$, Mita Nur Malasari $^{3}$
}

\author{
${ }_{1,2,3}$ STIKes Widya Dharma Husada Tangerang \\ *E-mail : sheila.meitania@gmail.com
}

\begin{abstract}
ABSTRAK
Bibir merupakan salah satu bagian wajah yang penampilannya mempengaruhi persepsi estetika wajah. Ekstrak etanol buah labu kuning (Curcubita moschata D.) telah diakui memiliki aktivitas antioksidan dengan menggunakan metde DPPH. Pada penelitian ini, 2\%, 4\% dan $8 \%$ ekstrak etanol buah labu kuning diformulasikan dalam bentuk lip balm karena berguna untuk melindungi dan menjaga kelembaban bibir. Tujuan penelitian ini adalah untuk mengetahui stabilitas fisik formulasi sediaan lip balm yang mengandung ekstrak etanol buah labu kuning. Uji stabilitas fisik dilakukan uji organoleptis, homogenitas, $\mathrm{pH}$, suhu lebur dan cycling test. Hasil penelitian menunjukkan bahwa ekstrak etanol buah labu kuning dapat diformulasikan dalam sediaan lip balm yang memiliki susunan yang homogen, $\mathrm{pH}$ yang sesuai $(5,8-6,3)$, suhu lebur yang baik $\left(55-59^{\circ} \mathrm{C}\right)$ dan stabil selama cycling test. Sediaan lip balm ekstrak etanl buah labu kuning dengan konsentrasi $8 \%$ memiliki stabilitas fisik yang paling baik.
\end{abstract}

Kata kunci: Stabilitas, lip balm, Curcubita moschata, buah labu kuning, cycling test.

\begin{abstract}
Lips is one part of the face whose appearance influences facial aesthetic perception. Ethanol extract pumpkin fruit (Curcubita moschata D.) has been recognized has antioxidant activity with use DPPH method. In this research, $2 \%, 4 \%$ and $8 \%$ ethanol extract pumpkin fruit formulated in the from of lip balm because it is useful to protect and maintain lip moisture. The purpose of this study was to determine the physical stability of the formulations of containing lip balm preparations. Physical stability test conducted by organoleptic test, homogeneity, $\mathrm{pH}$, melting temperature and cycling test. The result showed that the ethanol extract pumpkin fruit can be formulated in a lip balm preparation which has a homogeneous, $\mathrm{pH}$ is suitable $(5,8-6,3)$, good melting temperature $\left(55-59^{\circ} \mathrm{C}\right)$ and stable during cycling test. The preparations of the lip balm ethanol extract pumpkin fruit with a concentration of $8 \%$ had the best physical stability.
\end{abstract}

Keywords : Stability, lip balm, Curcubita moschata, pumpkin, cycling test.

\section{PENDAHULUAN}

Kosmetik adalah paduan beragam bahan yang siap digunakan pada bagian luar badan, seperti kulit, rambut, kuku, bibir, organ kelamin luar, gigi dan rongga mulut. Fungsinya untuk membersihkan, menambah daya tarik, mengubah penampilan, melindungi agar tetap baik, memperbaiki bau badan, tetapi tidak dimaksudkan untuk mengobati atau menyembuhkan suatu penyakit (Sari, 2011).

Bibir merupakan salah satu bagian wajah yang penampilannya mempengaruhi persepsi estetika wajah. Lapisan korneum pada bibir mengandung sekitar 3 sampai 4 lapis dan sangat tipis dibanding kulit wajah biasa. Kulit bibir tidak memiliki folikel rambut dan tidak ada kelenjar keringat yang berfungsi untuk melindungi bibir dari lingkungan luar. Akibat dari fungsi perlindungan yang 
buruk, bibir sangat rentan terhadap pengaruh lingkungan serta berbagai produk perawatan kesehatan, kosmetik dan produk perawatan kulit lainnya yang dapat menyebabkan kerusakan kulit yaitu bibir menjadi kering, pecah-pecah dan warna yang kusam. Selain tidak enak dipandang, bibir yang pecah-pecah juga menimbulkan rasa nyeri dan tidak nyaman (Balsam dan Sagarin, 2008).Selain lipstick dan lip gloss kosmetik bibir yang sering digunakan wanita adalah lip balm. Lip balm merupakan sediaan semipadat (krim padat) yang bertujuan untuk merawat atau melindungi bibir dan melembabkan kulit bibir. Lip balm merupakan balsam bibir yang mengandung zat pelembab dan vitamin untuk bibir (Muliyawan dan Suriana, 2013).

Labu kuning merupakan tanaman yang berasal dari benua Amerika terutama Negara Peru dan Meksiko (Brotodjojo, 2010). Buah ini kaya akan beta-karoten yang terbukti memiliki aktivitas melawan bahaya radikal bebas dan menurunkan resiko penyakit (Shi et al, 2013). Murkovic, Mulleder dan Neunteufl (2002) melaporkan bahwa tiga spesies labu (Curcubita pepo, Curcubita maxima dan Curcubita moschata) terdiri dari betakaroten $(0,06-7,4 \mathrm{mg} / 100 \mathrm{~g})$, alphakaroten $(0-7,5 \mathrm{mg} / 100 \mathrm{~g})$ dan lutein $(0-17 \mathrm{mg} / 100 \mathrm{~g})$. Buah labu kuning juga mengandung vitamin $\mathrm{A}$, vitamin $\mathrm{B} 1$, vitamin $\mathrm{C}$, protein, sterol dan flavonoid (Adlhani, 2014). Berdasarkan penelitian di China oleh Zhao, Liu, Chen, Song, Zhang, dan $\mathrm{Ni}$ (2015) spesies labu kuning Curcubita moschata memiliki kandungan beta-karoten terbesar dengan kadar 1,12 $\pm 0,03 \mathrm{mg}$ tiap 100 gram berat segar. Ellisa (2017) membuat formulasi sediaan sabun transparan dari sari buah labu kuning sebanyak $20 \%$ menghasilkan aktivitas antioksidan sebesar $169,91 \%$ menggunakan metode DPPH.

Stabilitas fisik sediaan bertujuan untuk mengetahui layak atau tidaknya suatu sediaan yang telah dibuat perlu dilakukan uji stabilitas fisiknya yang meliputi uji organoleptis, uji homogenitas, uji pH dan uji suhu lebur (Vadas, 2010).

Oleh karena itu, maka peneliti tertarik untuk melakukan uji stabilitas fisik formulasi sediaan lip balm yang mengandung ekstrak etanol buah labu kuning.

\section{BAHAN DAN METODE Bahan dan Alat}

Penelitian ini dilakukan di Laboratorium STIKes Kharisma Persada pada bulan Maret-Juni 2019. Bahan yang digunakan adalah ekstrak etanol buah labu kuning, cera alba, lanolin, gliserin, nipagin dan oleum cacao. Alat-alat yang digunakan adalah lupang dan alu, kaca arloji, kaca objek, gelas piala $100 \mathrm{~mL}$ (Pyrex), blender (Turbo), pH meter, timbangan analitik (UWE JW-250), hot plate (NESCO ${ }^{\circledR} \mathrm{LAB}$ ), oven (Memmert), pipet tetes, wadah lip balm, rotary evaporator, penangas air, moisture balance dan furnace.

\section{Jenis Penelitian}

Penelitian ini menggunakan jenis penelitian Eksperimental.

\section{Lokasi dan Waktu Penelitian}

\section{Lokasi Penelitian}

a. Pengambilan sampel daging buah labu kuning (Curcubita moschata D.) di peroleh dari Boyolali, Jawa Tengah.

b. Identifikasi buah labu kuning (Curcubita moschata D.) di Laboratorium Lembaga IImu Pengetahuan Indonesia (LIPI) Bogor.

c. Pembuatan ekstrak etanol buah labu kuning dilakukan di Laboratorium Farmasi Pusat Penelitian dan Pengembangan Biomedis dan Tekhnologi Dasar Kesehatan Kementerian Kesehatan Republik Indonesia (LITBANGKES).

d. Skrining fitokimia buah labu kuning (Curcubita moschata D.) dilakukan di Laboratorium Balai Penelitian Tanaman Rempah dan Obat (BALITTRO) Bogor. 
e. Pembuatan formulasi dan evaluasi formulasi sediaan Lip balm dari ekstrak etanol buah labu kuning (Curcubita moschata D.) dilakukan di Laboratorium Farmasi STIKes Widya Dharma Husada Tangerang.

2. Waktu Penelitian

Waktu penelitian di laksanakan pada bulan Januari sampai Juni 2019.

\section{Prosedur Penelitian}

1. Pembuatan Ekstrak Etanol Buah Labu Kuning (Curcubita moschata D.)

a. Preparasi Sampel

Buah labu kuning yang berumur 3 bulan diperoleh dari perkebunan yakni sebanyak $1 \mathrm{~kg}$ disortasi, dicuci, dirajang dan dikeringkan dengan cara dijemur di bawah sinar matahari hingga kering, setelah itu dihaluskan dengan blender.

b. Cara Ekstraksi

Proses selanjutnya ialah ekstraksi dengan metode maserasi dengan merendam $1 \mathrm{~kg}$ serbuk simplisia buah labu kuning ke dalam alkohol $70 \%$ selama 24 jam. Maserat buah labu kuning disaring menggunakan kertas saring. Penyaringan ini dilakukan 2 kali pengulangan. Selanjutnya filtrat hasil penyaringan dipekatkan menggunakan rotary evaporator hingga terbentuk ekstrak kental.

2. Formulasi Sediaan Lip Balm yang Mengandung Ekstrak Buah Labu Kuning (Curcubita moschata D.)

Formulasi sediaan lip balm untuk pengujian stabilitas fisik terdiri dari tiga formulasi dengan variasi konsentrasi ekstrak etanol buah labu kuning yang digunakan yaitu $2 \%, 4 \%$ dan $8 \%(\mathrm{~b} / \mathrm{b})$. Perhitungan persentase komposisi bahan masing-masing sediaan lip balm dapat dilihat pada Tabel 1 (berat bersih sediaan $50 \mathrm{~g}$ ).

Cara Pembuatan Sediaan Lip Balm:

a. Ditimbang semua bahan yang digunakan

b. Lanolin, cera alba dan oleum cacao dilebur diatas penangas air menggunkan cawa penguap sambil diaduk hingga meleleh sempurna (M1).

c. Dihaluskan ekstrak buah labu kuning dengan air panas lalu masukkan nipagin dan gliserin (M2).

d. Dimasukkan leburan kedalam lumpang dan gerus hingga terbentuk basis.

e. Dimasukkan M2 kedalam basis dan gerus hingga bercampur sempurna.

f. Setelah itu lip balm dimasukkan kedalam wadah lalu dibiarkan pada suhu ruangan sampai membeku.

\section{Evaluasi Sediaan Lip Balm}

1. Uji Stabilitas Fisik

a. Uji Organoleptis

Pengamatan organoleptis dilakukan dengan mengamati sediaan krim secara visual dari segi warna, homogenitas dan tekstur. Proses dilakukan pada setiap penyampelan (Khullar et al, 2012).

b. Uji Homogenitas

Masing-masing sediaan diperiksa homogenitasnya dengan cara mengoleskan $0,1 \mathrm{~g}$ sampel sediaan pada kaca transparan. Sediaan harus menunjukkan susunan yang homogen dan tidak terlihat adanya butir-butir kasar (DepKes RI, 2014).

c. $\quad$ ji pH

Penentuan $\mathrm{pH}$ sediaan dilakukan dengan menggunakan alat $\mathrm{pH}$ meter dengan cara :

Alat terlebih dahulu dikalibrasi dengan menggunakan larutan dapar standar netral $(\mathrm{pH} \mathrm{7,01)}$ dan larutan dapar asam $(\mathrm{pH} \mathrm{4,01)} \mathrm{hingga} \mathrm{alat} \mathrm{menunjukkan} \mathrm{harga} \mathrm{pH}$ tersebut. Kemudian 
elektroda dicuci dengan aquadest, lalu dikeringkan dengan tisu. Sampel dibuat dalam konsentrasi $1 \%$ yaitu ditimbang 1 gram sediaan dan dilarutkan dalam $100 \mathrm{~mL}$ aquadest, lalu dipanaskan. setelah suhu larutan normal, elektroda dicelupkan dalam larutan tersebut. Dibiarkan alat menunjukkan harga $\mathrm{pH}$ sampai konstan. Angka yang ditunjukkan $\mathrm{pH}$ meter merupakan $\mathrm{pH}$ sediaan (Rawlin, 2003).

d. Suhu Lebur Sediaan

Metode pengamatan suhu lebur lip balm yang digunakan dalam penelitian adalah dengan cara memasukkan lip balm ke dalam oven dengan suhu awal $50^{\circ} \mathrm{C}$ selama 15 menit, diamati apakah melebur atau tidak, setelah itu suhu dinaikkan $1^{\circ} \mathrm{C}$ setiap 15 menit dan diamati pada suhu berapa lip balm mulai melebur (Tranggono dan Latifah, 2007).

2. Uji Stabilitas Dipercepat

a. Cycling Test

Sediaan lip balm disimpan pada suhu $\left(4^{\circ} \mathrm{C} \pm 2^{\circ} \mathrm{C}\right)$ selama 24 jam, kemudian dipindahkan ke dalam oven yang bersuhu $\left(40^{\circ} \mathrm{C} \pm 2^{\circ} \mathrm{C}\right)$ selama 24 jam (satu siklus). Uji ini dilakukan sebanyak 6 siklus atau selama 12 hari kemudian diamati terjadi perubahan (Cannell, 2008).

\section{Etika Penelitian}

Dalam penelitian ini, peneliti tidak melibatkan manusia dan hewan untuk melakukan percobaan penelitian tetapi menggunakan daging buah labu kuning (Curcubita moschata D.).

\section{HASIL DAN PEMBAHASAN}

\section{Formulasi Sediaan Lip Balm Ekstrak Etanol Buah Labu Kuning (Curcubita moschata D.)}

Tabel 1.Formulasi Sediaan Lip Balm Ekstrak Etanol Buah Labu Kuning (Curcubita moschata D.)

\begin{tabular}{crrrl}
\hline \multirow{2}{*}{ Bahan } & \multicolumn{3}{c}{ Formula (b/b) } & \multirow{2}{*}{ Kegunaan } \\
\cline { 2 - 4 } & F I & F II & F III & \\
\hline Ekstrak Buah & $2 \%$ & $4 \%$ & $8 \%$ & Zat Aktif \\
Labu Kuning & & & & \\
Lanolin & $10 \%$ & $10 \%$ & $10 \%$ & Emulient \\
Cera Alba & $20 \%$ & $20 \%$ & $20 \%$ & Emulient \\
Gliserin & $10 \%$ & $10 \%$ & $10 \%$ & Pelembab \\
Nipagin & $0,1 \%$ & $0,1 \%$ & $0,1 \%$ & Pengawet \\
Oleum Cacao & $57,9 \%$ & $55,9 \%$ & $51,9 \%$ & Pengeras \\
\hline
\end{tabular}

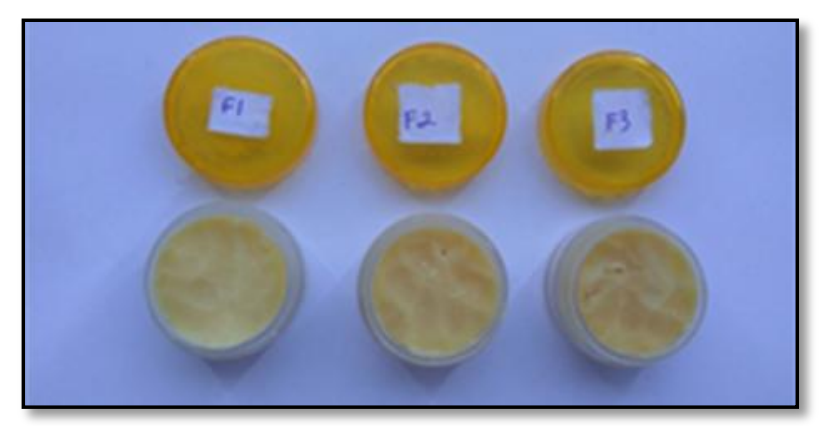

Gambar 1. Hasil Formulasi Sediaan Lip Balm Ekstrak Etanol Buah Labu Kuning (Curcubita moschata D.)

Keterangan:

$\mathrm{F} \mathrm{I} \mathrm{=} \mathrm{Formula} \mathrm{lip} \mathrm{balm} \mathrm{dengan} \mathrm{konsentrasi} \mathrm{ekstrak}$ etanol buah labu kuning $2 \%$

F II= Formula lip balm dengan konsentrasi ekstrak etanol buah labu kuning $4 \%$

FIII= Formula lip balm dengan konsentrasi ekstrak etanol buah labu kuning $8 \%$. 
Berdasarkan Tabel 1. dan Gambar 1. Hasil formulasi sediaan lip balm dengan ekstrak etanol buah labu kuning dibuat menjadi 3 variasi konsentrasi yaitu pada formulasi I mengandung ekstrak etanol buah labu kuning $2 \%(\mathrm{FI})$, lanolin $10 \%$, cera alba $20 \%$, gliserin $10 \%$ nipagin $0,1 \%$, lemak coklat 57,9\%; pada formulasi II mengandung ekstrak etanol buah labu kuning $4 \%$ (FII) dan formulasi III 8\% (FIII).

Pada penelitian ini sampel yang digunakan adalah daging buah labu kuning (Curcubita moschata D.) yang berumur 3 bulan. Buah labu kuning diperoleh dari Boyolali, Jawa Tengah, kemudian dilakukan identifikasi tanaman di Laboratorium Lembaga IImu Pengetahuan Indonesia (LIPI) Bogor, Jawa Barat. Identifikasi ini dilakukan untuk mencegah terjadinya kesalahan dalam pengambilan bahan utama yang akan digunakan dalam penelitian.

Sebanyak $1 \mathrm{~kg}$ serbuk simplisia buah labu kuning diekstraksi dengan menggunakan metode maserasi, alasan menggunakan metode maserasi adalah untuk menarik zat-zat berkhasiat yang tahan pemanasan maupun yang tidak tahan pemanasan dengan pengerjaan dan peralatan yang sangat sederhana dengan menggunakan penyari alkohol 70\% (DepKes RI, 2014). Etanol 70\% merupakan penyari yang sangat baik karena dapat menarik senyawa polar maupun non polar (Rowe et al, 2009). Etanol yang digunakan dalam penelitian ini sebanyak 13 Liter, menghasilkan rendemen ekstrak sebesar $14,29 \%$.

Ekstrak etanol buah labu kuning yang sudah kental, kemudian di uji fitokimia di Laboratorium Balai Penelitian Tanaman Rempah dan Obat (BALITTRO) Bogor, Jawa Barat. Ekstrak etanol buah labu kuning mengandung alkaloid, saponin, fenolik, flavonoid, triterpenoid dan glikosida. Ekstrak etanol buah labu kuning memiliki bau khas, rasa agak manis dan warna kecoklatan. Ekstrak etanol buah labu kuning diuji karakteristik ekstrak di LITBANGKES mengandung kadar air ekstrak $18,26 \%$, kadar abu total $0,84 \%$, kadar sari larut etanol $81,25 \%$ dan kadar sari larut air $17,58 \%$.

Formulasi sediaan lip balm dibuat menjasi 3 variasi konsentrasi ekstrak etanol buah labu kuning sebagai zat aktifnya. Tujuan dilakukannya perbedaan ekstrak etanol buah labu kuning untuk mengetahui formulasi sediaan lip balm mana yang memiliki stabilitas yang paling baik. Stabilitas dari sediaan itu sendiri bertujuan untuk mengetahui kualitas dari sediaan tersebut aman dan bertahan lama, sehingga dapat disimpan dalam jangka waktu yang lama tanpa menurunkan khasiat atau manfaat dari sediaan tersebut (Syakdiah, 2018).

Proses pembuatan sediaan lip balm dengan melebur oleum cacao, lanolin, cera alba dan gliserin dalam cawan penguap menggunakan hot plate, dalam lumpang gerus ekstrak etanol buah labu kuning kemudian ditambahkan campuran lemburan tersebut lalu sediaan digerus hingga homogen kemudian ditambahkan nipagin lalu digerus hingga homogen dan dimasukkan ke dalam kemasan. Penggunaan lanolin sebagai emolien karena sering digunakan dalam sediaan topikal, cera alba sebagai emolien karena dianggap tidak toksik dan tidak mengiritasi pada sediaan topikal dan oral, gliserin digunakan sebagai pelembab karena digunakan secara luas pada sediaan oral maupun topikal, nipagin digunakan sebagai pengawet untuk sediaan kosmetika dan makanan karena lip balm digunakan pada bibir dan cara penggunaannya dioleskan langsung menggunakan tangan sehingga perlu penambahan pengawet antimikroba agar sediaan lip balm yg dibuat aman, oleum cacao (lemak coklat) sebagai pengeras untuk sediaan lip balm karena oleum cacao sering digunakan dalam produk kecantikan yang berfungsi sebagai pelembab kulit (Rowe et al, 2009).

Berdasarkan Tabel 1. formulasi sediaan lip balm dibuat menjadi 3 variasi konsentrasi ekstrak etanol buah labu kuning sebagai zat aktif, yaitu pada formulasi I mengandung ekstrak etanol buah labu kuning sebanyak $2 \%$ (FI), formulasi II sebanyak $4 \%$ (FII) dan formulasi III sebanyak $8 \%$ (FIII). 
2. Evaluasi Sediaan Lip Balm Ekstrak Etanol Buah Labu Kuning (Curcubita moschata D.) a. Uji Organoleptis

Tabel 2. Hasil Uji Organoleptis Sediaan Lip Balm Ekstrak Etanol Buah Labu Kuning (Curcubita moschata D.)

\begin{tabular}{|c|c|c|c|c|c|c|}
\hline Minggu Ke- & Suhu & Organoleptis & FI & FII & & FIII \\
\hline \multirow{6}{*}{0} & \multirow{3}{*}{$25 \pm 2^{\circ} \mathrm{C}$} & Warna & $\begin{array}{l}\text { Kuning Pucat } \\
\text { (PMS 120) }\end{array}$ & $\begin{array}{l}\text { Kuning } \\
\text { (PMS 121) }\end{array}$ & Pucat & $\begin{array}{l}\text { Kuning (PMS } \\
122)\end{array}$ \\
\hline & & Bentuk & Padat & Padat & & Semi Padat \\
\hline & & Aroma & Khas & Khas & & Khas Lemah \\
\hline & \multirow{3}{*}{$4 \pm 2^{\circ} \mathrm{C}$} & Warna & $\begin{array}{l}\text { Kuning Pucat } \\
\text { (PMS 120) }\end{array}$ & $\begin{array}{l}\text { Kuning } \\
\text { (PMS 121) }\end{array}$ & Pucat & $\begin{array}{l}\text { Kuning (PMS } \\
\text { 122) }\end{array}$ \\
\hline & & Bentuk & Padat & Padat & & Semi Padat \\
\hline & & Aroma & Khas & Khas & & Khas Lemah \\
\hline \multirow[t]{2}{*}{ Minggu Ke- } & \multirow[t]{2}{*}{ Suhu } & Organoleptis & FI & FII & & FIII \\
\hline & & Warna & $\begin{array}{l}\text { Kuning Pucat } \\
\text { (PMS 120) }\end{array}$ & $\begin{array}{l}\text { Kuning } \\
\text { (PMS 121) }\end{array}$ & Pucat & $\begin{array}{l}\text { Kuning (PMS } \\
122)\end{array}$ \\
\hline \multirow[t]{5}{*}{0} & \multirow[t]{2}{*}{$40 \pm 2^{\circ} \mathrm{C}$} & Bentuk & Padat & Padat & & Semi Padat \\
\hline & & Aroma & Khas & Khas & & Khas Lemah \\
\hline & \multirow[t]{2}{*}{$25 \pm 2^{\circ} \mathrm{C}$} & Warna & $\begin{array}{l}\text { Kuning Pucat } \\
\text { (PMS 120) } \\
\text { Padat }\end{array}$ & $\begin{array}{l}\text { Kuning } \\
\text { (PMS 121) } \\
\text { Padat }\end{array}$ & Pucat & $\begin{array}{l}\text { Kuning (PMS } \\
\text { 122) } \\
\text { Semi Padat }\end{array}$ \\
\hline & & Aroma & Khas & Khas & & Khas Lemah \\
\hline & $4 \pm 2^{\circ} \mathrm{C}$ & Warna & $\begin{array}{l}\text { Kuning Pucat } \\
\text { (PMS 120) }\end{array}$ & $\begin{array}{l}\text { Kuning } \\
\text { (PMS 121) }\end{array}$ & Pucat & $\begin{array}{l}\text { Kuning (PMS } \\
122)\end{array}$ \\
\hline \multirow[t]{9}{*}{4} & & Bentuk & Padat & Padat & & Semi Padat \\
\hline & & Aroma & Khas Lemah & Khas Lemah & & Khas Lemah \\
\hline & \multirow[t]{4}{*}{$40 \pm 2^{\circ} \mathrm{C}$} & Warna & $\begin{array}{l}\text { Kuning Pucat } \\
\text { (PMS 120) }\end{array}$ & $\begin{array}{l}\text { Kuning } \\
\text { (PMS 121) }\end{array}$ & Pucat & $\begin{array}{l}\text { Kuning (PMS } \\
122)\end{array}$ \\
\hline & & Bentuk & Semi Padat & Semi Padat & & Semi Padat \\
\hline & & Aroma & Khas & Khas & & Khas \\
\hline & & Warna & $\begin{array}{l}\text { Kuning Pucat } \\
\text { (PMS 120) }\end{array}$ & $\begin{array}{l}\text { Kuning } \\
\text { (PMS 121) }\end{array}$ & Pucat & $\begin{array}{l}\text { Kuning (PMS } \\
122)\end{array}$ \\
\hline & \multirow[t]{3}{*}{$25 \pm 2^{\circ} \mathrm{C}$} & Bentuk & Padat & Padat & & Semi Padat \\
\hline & & Aroma & Khas & Khas & & Khas Lemah \\
\hline & & Warna & $\begin{array}{l}\text { Kuning Pucat } \\
\text { (PMS 120) }\end{array}$ & $\begin{array}{l}\text { Kuning } \\
\text { (PMS 121) }\end{array}$ & Pucat & $\begin{array}{l}\text { Kuning (PMS } \\
122)\end{array}$ \\
\hline \multirow[t]{5}{*}{8} & \multirow[t]{3}{*}{$4 \pm 2^{\circ} \mathrm{C}$} & Bentuk & Padat & Padat & & Semi Padat \\
\hline & & Aroma & Khas Lemah & Khas Lemah & & Khas Lemah \\
\hline & & Warna & $\begin{array}{l}\text { Kuning Pucat } \\
\text { (PMS 120) }\end{array}$ & $\begin{array}{l}\text { Kuning } \\
\text { (PMS 121) }\end{array}$ & Pucat & $\begin{array}{l}\text { Kuning (PMS } \\
122)\end{array}$ \\
\hline & \multirow[t]{2}{*}{$40 \pm 2^{\circ} \mathrm{C}$} & Bentuk & Semi Padat & Semi Padat & & Semi Padat \\
\hline & & Aroma & Khas & Khas & & Khas \\
\hline
\end{tabular}


Dari pengujian organoleptis berdasarkan hasil pengamatan dan literatur didapatkan bahwa sediaan lip balm memiliki stabilitas paling baik pada suhu kamar. Hal ini karena sediaan yang disimpan pada suhu kamar tidak mengalami perubahan pada bentuk sediaan dibandingkan sediaan yang disimpan pada suhu dingin akan mengalami perubahan bentuk menjadi padat dan sediaan yang disimpan pada suhu panas akan mengalami perubahan menjadi setengah padat.

b. Uji Homogenitas

Tabel 3. Hasil Uji Homogenitas Sediaan Lip Balm Ekstrak Etanol Buah Labu Kuning (Curcubita moschata D.)

\begin{tabular}{clll}
\hline Minggu Ke- & FI & FII & FIII \\
\hline $\mathbf{0}$ & Homogen & Homogen & Homogen \\
$\mathbf{2}$ & Homogen & Homogen & Homogen \\
$\mathbf{4}$ & Homogen & Homogen & Homogen \\
$\mathbf{6}$ & Homogen & Homogen & Homogen \\
$\mathbf{8}$ & Homogen & Homogen & Homogen \\
\hline
\end{tabular}

Dari hasil pengujian homogenitas selama 8 minggu penyimpanan didapatkan bahwa semua sediaan lip balm ekstrak etanol buah labu kuning homogen karena tidak terdapat butiran kasar pada sediaan.

c. Uji pH

Tabel 4. Hasil Uji pH Sediaan Lip Balm Ekstrak Etanol Buah Labu Kuning (Curcubita moschata D.)

\begin{tabular}{cccccccccc}
\hline \multirow{2}{*}{ Minggu ke- } & \multicolumn{8}{c}{ Ruang $\left(\mathbf{2 5}^{\circ} \mathrm{C} \pm \mathbf{2}^{\circ} \mathrm{C}\right)$} & \multicolumn{3}{c}{ Dingin $\left(\mathbf{4}^{\circ} \mathrm{C} \pm \mathbf{2}^{\circ} \mathrm{C}\right)$} & \multicolumn{3}{c}{ Panas $\left(\mathbf{4 0}{ }^{\circ} \mathrm{C} \pm \mathbf{2}^{\circ} \mathrm{C}\right)$} \\
& $\mathbf{F 1}$ & $\mathbf{F 2}$ & $\mathbf{F 3}$ & $\mathbf{F 1}$ & $\mathbf{F 2}$ & $\mathbf{F 3}$ & $\mathbf{F 1}$ & $\mathbf{F 2}$ & F3 \\
\hline $\mathbf{0}$ & 6,23 & 6,2 & 5,93 & 6,23 & 6,2 & 5,9 & 6,3 & 6,2 & 5,9 \\
$\mathbf{2}$ & 6,27 & 6,2 & 5,9 & 6,23 & 6,23 & 6,0 & 6,13 & 6,23 & 5,83 \\
$\mathbf{4}$ & 6,37 & 6,23 & 5,87 & 6,3 & 6,23 & 5,9 & 6,37 & 6,23 & 5,97 \\
$\mathbf{6}$ & 6,2 & 6,23 & 5,9 & 6,23 & 6,2 & 5,9 & 6,4 & 6,3 & 5,9 \\
$\mathbf{8}$ & 6,3 & 6,3 & 5,6 & $\mathbf{6 , 3}$ & 6,1 & 5,9 & 6,23 & 6,3 & 6,0 \\
Rata-Rata & $\mathbf{6 , 3}$ & $\mathbf{6 , 2}$ & $\mathbf{5 , 9}$ & $\mathbf{6 , 2}$ & $\mathbf{6 , 1}$ & $\mathbf{5 , 9}$ & $\mathbf{6 , 2}$ & $\mathbf{6 , 2}$ & $\mathbf{5 , 8}$ \\
\hline
\end{tabular}

Dari hasil pengamatan sediaan lip balm yang dibuat dengan menggunakan ekstrak etanol buah labu kuning memiliki pH 5,8-6,3. Perbedaan nilai pH sediaan disebabkan oleh perbedaan konsentrasi ekstrak etanol buah labu kuning yang digunakan. $\mathrm{pH}$ sediaan lip balm berada di rentang $\mathrm{pH}$ fisiologis kulit yaitu 4,5-6,5. Semakin alkalis atau semakin asam bahan yang mengenai kulit, semakin sulit kulit untuk menetralisirnya dan kulit menjadi kering, pecah-pecah, sensitif dan mudah terinfeksi. Oleh karena itu $\mathrm{pH}$ kosmetika diusahakan sama atau sedekat mungkin dengan $\mathrm{pH}$ fisiologis kulit yaitu antara 4,5-6,5 (Tranggono dan Latifah, 2007). Berdasarkan hasil pengamatan dan literatur yang ada, dapat disimpulkan bahwa semua sediaan lip balm yang mengandung ekstrak etanol buah labu kuning memiliki nilai $\mathrm{pH}$ yang aman untuk digunakan pada bibir karena tidak mengiritasi bibir dengan rentang nilai pH 5,8-6,3. 
d. Uji Suhu Lebur

Tabel 5. Hasil Uji Suhu Lebur Sediaan Lip Balm Ekstrak Etanol Buah Labu Kuning (Curcubita moschata D.)

\begin{tabular}{cc}
\hline Formulasi & Suhu $\left({ }^{\circ} \mathrm{C}\right)$ \\
\hline F1 & 59 \\
F2 & 57 \\
F3 & 55 \\
\hline
\end{tabular}

Suhu lebur yang ideal sesungguhnya adalah yang mendekati suhu bibir bervariasi $36-38^{\circ} \mathrm{C}$. Tetapi karena harus memperhatikan ketahanan terhadap suhu cuaca sekelilingnya, terutama pada suhu daerah tropik sehingga suhu diatur pada suhu lebih kurang $65^{\circ} \mathrm{C}$ biasanya berkisar antara $55-65^{\circ} \mathrm{C}$ berdasarkan hasil uji suhu lebur (Tabel 5 ) sediaan lip balm melebur pada rentang suhu $55-59^{\circ} \mathrm{C}$.

e. Cycling Test

Tabel 6. Hasil Pengamatan Cycling Test Sediaan Lip BalmEkstrak Etanol Buah Labu Kuning (Curcubita moschata D.)

\begin{tabular}{|c|c|c|c|c|c|}
\hline \multirow{2}{*}{ Formulasi } & \multirow{2}{*}{$\begin{array}{c}\text { Siklus } \\
\text { Ke- }\end{array}$} & \multirow{2}{*}{$\mathrm{pH}$} & \multicolumn{3}{|c|}{ Organoleptis } \\
\hline & & & Warna & Bentuk & Bau \\
\hline \multirow[t]{2}{*}{1} & 1 & 6,16 & Kuning Pucat (PMS 120) & Padat & Khas \\
\hline & 6 & 6,0 & Kuning Pucat (PMS 120) & Padat & Khas \\
\hline \multirow[t]{2}{*}{ II } & 1 & 5,96 & Kuning Pucat (PMS 121) & Padat & Khas \\
\hline & 6 & 5,96 & Kuning Pucat (PMS 121) & Padat & Khas \\
\hline \multirow[t]{2}{*}{ III } & 1 & 5,83 & Kuning (PMS 122) & $\begin{array}{l}\text { Semi } \\
\text { Padat }\end{array}$ & Khas Lemah \\
\hline & 6 & 5,86 & Kuning (PMS 122) & $\begin{array}{l}\text { Semi } \\
\text { Padat }\end{array}$ & Khas Lemah \\
\hline
\end{tabular}

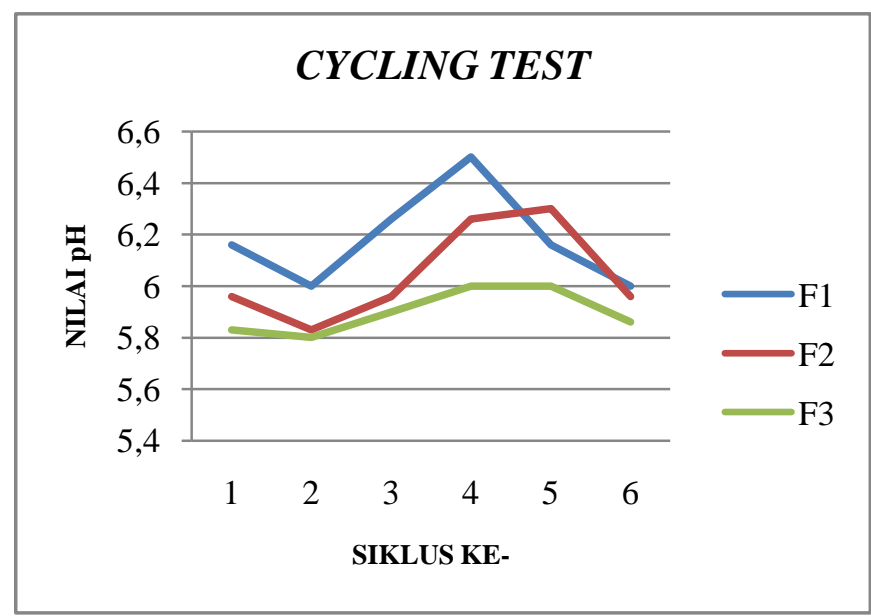

Gambar 2. Grafik Hasil Uji pH Cycling Test Sediaan Lip BalmEkstrak Etanol Buah Labu Kuning (Curcubita moschata D.) 
Pada siklus ke- 1 sampai siklus ke-6 tidak terjadi perubahan warna, homogenitas dan $\mathrm{pH}$ yang terlalu signifikan, nilai $\mathrm{pH}$ sediaan lip balm yang dibuat antara 5,8-6,3, namun terjadi sedikit perubahan pada bentuk sediaan lip balm selama proses cycling. Apabila selama proses cycling tidak terjadi perubahan yang signifikan, dapat diartikan bahwa produk stabil selama proses distribusi (Djajadisastra et al, 2009). Hal ini menyatakan bahwa sediaan lip balm yang mengandung ekstrak etanol buah labu kuning (Curcubita moschata D.) memiliki stabilitas yang baik karena tidak terjadi perubahan warna, homogenitas maupun nilai $\mathrm{pH}$ yang signifikan.

Evaluasi sediaan lip balm ekstrak buah labu kuning meliputi uji stabilitas fisik (uji organoleptis, homogenitas, $\mathrm{pH}$ dan suhu lebur) dan uji stabilitas dipercepat (cycling test). Uji stabilitas fisik organoleptis, homogenitas dan $\mathrm{pH}$ dilakukan selama 8 minggu dengan pengujian fisik tiap 1 minggu sekali. Uji suhu lebur dilakukan pada awal pembuatan sediaan lip balm. Uji stabilitas dipercepat dilakukan selama 6 siklus (12 hari).

Uji organoleptis dilakukan untuk mengetahui perubahan warna, bentuk dan bau selama penyimpanan (Sriwidodo, 2013). Berdasarkan hasil pengamatan dan literatur didapatkan bahwa sediaan lip balm memiliki stabilitas paling baik pada suhu kamar. Hal ini karena sediaan yang disimpan pada suhu kamar tidak mengalami perubahan pada bentuk dibandingkan sediaan yang disimpan pada suhu dingin akan mengalami perubahan bentuk menjadi padat dan sediaan yang disimpan pada suhu panas akan mengalami perubahan menjadi setengah padat.

Uji homogenitas bertujuan untuk melihat sediaan lip balm homogen atau tidak. Berdasarkan hasil pengamatan uji homogenitas sediaan lip balm dari ekstrak etanol buah labu kuning (Curcubita moschata D.) dengan variasi konsentrasi 2\% (FI), 4\% (FII) dan 8\% (FIII).

Homogenitas sediaan ditunjukkan dengan ada tidaknya butiran kasar pada sediaan (DepKes RI, 2014). Menurut Syamsuni (2005) mengenai uji homogenitas sediaan dikatakan homogen apabila pada saat diraba tidak ditemukan adanya partikel kasar dan memiliki warna yang merata.

Berdasarkan hasil pengamatan dan literatur didapatkan bahwa sediaan lip balm dari ekstrak etanol buah labu kuning (Curcubita moschata D.) memiliki homogenitas yang baik karena tidak terlihat butiran kasar pada sediaan, maka ketiga formulasi sediaan lip balm yang dibuat dinyatakan homogen.

Pada penelitian ini dilakukan uji pH pada sediaan lip balm dari ekstrak etanol buah labu kuning untuk mengetahui derajat keasaman dari sediaan lip balm yang dihasilkan.

Sediaan yang dibuat dengan menggunakan ekstrak etanol buah labu kuning memiliki $\mathrm{pH}$ $5,8-6,3$. Perbedaan nilai $\mathrm{pH}$ sediaan disebabkan oleh perbedaan konsentrasi ekstrak etanol buah labu kuning yang digunakan. $\mathrm{pH}$ sediaan lip balm berada di rentang $\mathrm{pH}$ fisiologis kulit yaitu 4,5-6,5. Semakin alkalis atau semakin asam bahan yang mengenai kulit, semakin sulit kulit untuk menetralisirnya dan kulit menjadi kering, pecah-pecah, sensitif dan mudah terinfeksi. Oleh karena itu $\mathrm{pH}$ kosmetika diusahakan sama atausedekat mungkin dengan $\mathrm{pH}$ fisiologis kulit yaitu antara 4,5-6,5 (Tranggono dan Latifah, 2007).

Berdasarkan hasil pengamatan dan literatur yang ada, dapat disimpulkan bahwa semua sediaan lip balm yang mengandung ekstrak etanol buah labu kuning memiliki nilai $\mathrm{pH}$ yang aman untuk digunakan pada bibir karena tidak mengiritasi bibir dengan rentang nilai pH 5,8-6,3.

Berdasarkan hasil pemeriksaan suhu lebur sediaan lip balm menunjukkan bahwa sediaan lip balm ekstrak etanol buah labu kuning berkisar antara $55^{\circ} \mathrm{C}-59^{\circ} \mathrm{C}$. $\mathrm{FI}$ melebur pada suhu $59^{\circ} \mathrm{C}$, FII $57^{\circ} \mathrm{C}$ dan formulasi $I I I 55^{\circ} \mathrm{C}$, hal ini terjadi karena perbedaan konsentrasi lemak coklat yang digunakan, semakin sedikit lemak coklat yang digunakan, maka semakin rendah suhu lebur sediaan lip balm.

Suhu lebur sediaan lip balm yang ideal diatur hingga suhu yang mendekati suhu bibir, bervariasi antara $36-38^{\circ} \mathrm{C}$. Tetapi karena harus memperhatikan faktor ketahanan terhadap suhu cuaca sekelilingnya, terutama suhu tropis, suhu lebur lip balm dibuat lebih tinggi, yaitu berkisar 55$75^{\circ} \mathrm{C}$ agar tidak meleleh apabila disimpan pada suhu ruang dan mempertahankan bentuknya 
selama proses distribusi, penyimpanan dan pemakaian (Fernandes, dkk, 2013). Suhu lebur lip balm berdasarkan SNI 16-5769-1998 yaitu $50-70^{\circ} \mathrm{C}$ (Tranggono dan Latifah, 2007).

Berdasarkan hasil pengamatan dan literatur yang didapatkan bahwa sediaan lip balm dengan konsentrasi ekstrak etanol buah labu kuning telah memenuhi persyaratan suhu lebur karena memiliki nilai suhu lebur yang sesuai yaitu antara $55-59^{\circ} \mathrm{C}$.

Berdasarkan hasil pengamatan cycling test sediaan lip balm, uji ini dilakukan selama 6 siklus pada suhu $4^{\circ} \mathrm{C}$ dan $40^{\circ} \mathrm{C}$. FI memiliki warna kuning pucat (PMS 120) dan Fll memiliki warna sediaan kuning pucat (PMS 121), berbentuk padat, homogen dan memiliki aroma khas coklat, sedangkan FIII memiliki warna sediaan kuning (PMS 122), berbentuk semi padat, homogen dan memiliki aroma khas lemah coklat, hal ini terjadi karena perbedaan kandungan lemak coklat dalam formulasi, FIII mengandung lemak coklat yang lebih sedikit dibandingkan FI dan FII sehingga FIII memiliki warna, bentuk dan aroma yang berbeda. Apabila selama proses cycling tidak terjadi perubahan yang signifikan, dapat diartikan bahwa produk stabil selama proses distribusi (Djajadisastra et al, 2009). Hal ini menyatakan bahwa sediaan lip balm yang mengandung ekstrak etanol buah labu kuning (Curcubita moschata D.) memiliki stabilitas yang baik karena tidak terjadi perubahan warna, homogenitas maupun nilai $\mathrm{pH}$ yang signifikan.

\section{SIMPULAN}

Berdasarkan uji stabilitas fisik dan stabilitas dipercepat, formulasi sediaan yang memiliki stabilitas yang paling baik adalah sediaan lip balm dengan konsentrasi $8 \%$ (FIII) karena memiliki bentuk, warna seperti labu kuning, nilai $\mathrm{pH}$ dan tekstur yang lebih baik dibandingkan formulasi dengan konsentrasi $2 \%(\mathrm{FI})$ dan konsentrasi $4 \%$ (FII).

\section{REFERENSI}

Balsam, M. S., Sagarin, E. (2008). Cosmetics Science and Technolgy Second Edition. USA: Wiley Interscience Publication. Hal: 209-512.

Brotodjojo, L. C. (2010). Semua Serba Labu Kuning. Jakarta: PT Gramedia.

Cannell, R. J. P. (2008). Natural Product Isolation. New Jersey: Humana Press.

DepKes RI. (2014). Farmakope Indonesia Edisi V. Jakarta: Depkes RI.

Djajadisastra. J., Abdul. M., Dessy, M. P. (2009). Formulasi Gel Topical Dari Ekstrak Nerii Folium Dalam Sediaan Anti Jerawat. Jurnal Farmasi Indonesia 4(4):210-216.

Ellisa, Widjanarko. (2017). Formulasi Sediaan Sabun Transparan Ekstrak Labu Kuning (Curcubita moschata). Surabaya: Fakultas Farmasi Universitas Katolik Widya Mandala.

Khullar R., Kumar D., Seth N., Saini S. (2012). Formulation And Evaluation Of Mefenamic Acid Emulgel For Topical Delivery. Saudi pharmaceutical journal 20(1): 63-67.

Muliyawan D., dan Suriana, N. (2013). A - Z Tentang Kosmetik. Jakarta: PT. Elex Media Komputindo. Murkovic, M., Mulleder, U., Neunteufl, H. (2002). 'Carotenoid Content In Different Varieties Of Pumpkin'. Journal of Food Composition and analysis. 15(6): 633-638.

Rowe, R.C, Sheskey, P. J. and Quinn, M. E. (2009). Handbook of Pharmaceutical Exipients, 6th Ed, The Pharmaceutical Press, london

Rawlins, E. (2003). Bentleys of Pharmaceutics, Eighteen ed. London: Baillierre Tindall.

Sari, N. R. (2011). All About Cosmetics. Cara Pintar Memilih Kosmetik. Jakarta: Mocomedia.

Shi, X., Wu, H., Shi, J., Xue, S. J., Wang, D., Wang, W., Cheng, A., Gong, Z., Chen, X., Wang, C. (2013). "Effect of Modifier on The Composition and Antioxidant Activity of Carotenoid Extract From Pumpkin by Supercritical CO2, LWWT Food Science and Technology, 51(2): 433-440.

Sriwidodo. (2013). Formulasi Sabun Cair dengan Lendir Lidah Buaya. Sumedang: Fakultas Farmasi FMIPA UNPAD.

Syakdiah, K. (2018). Formulasi Sediaan Lip Balm yang Mengandung Minyak Buah Merah (Red fruit oil) Sebagai Pelembab Bibir. Medan: Fakultas Farmasi Universitas Sumatera Utara.

Syamsuni. (2005). Farmasetika Dasar dan Hitungan Farmasi. Jakarta: ECG. 
Tranggono, R. I. S., dan Latifah, F. (2007). Buku Pegangan IImu Pengetahuan Kosmetik. Jakarta: Gramedia Pustaka Utama

Vadas,E.B. (2010). Stability of Pharmaceutical Product, dalam Remington: The Science and Practice of Pharmacy. Volume 1. Editor: Alfonso Gennaro. London: Lippincott Williams \% Wilkins. Halaman 988-989.

Zhao, J., Liu, W., Chen, D., Song, Y., Zang, Y., Ni, Y., Li, Q. (2015). 'Physicochemical and Antioxidant Properties of Different Pumpkin Cultivars Grown in China'. Advance Journal of Food Science and Technology. 9(4): 308-316. 